\title{
La JunTa DE DEPENDENCIAS DE EXTRANJEROS (1714-1800): TrasFondo SOCIO-POLÍTICO DE UNA HISTORIA INSTITUCIONAL*
}

\author{
ANA CRESPo SOLANA \\ Instituto de Historia, CSIC \\ ViCENTE MONTOJO MONTOJO \\ Archivo General de la Región de Murcia
}

RESUMEN: Este trabajo de investigación tiene como objetivo el análisis de la Junta de Dependencias de Extranjeros, una institución entendida en el marco reformista del gobierno de Felipe $V$ de Borbón, tras la Guerra de Sucesión española, creada con la finalidad de vigilar y controlar las actividades de los mercaderes no autóctonos asentados en muchas ciudades españolas. A lo largo de su existencia desarrolló, además, una fuerte capacidad de interlocución y receptividad con los componentes de dichas comunidades. Se han utilizado fuentes primarias originales, como son los expedientes tramitados por la junta, generalmente peticiones y reclamaciones de comerciantes y comunidades, e informes sobre los nombramientos de cónsules extranjeros, conservados en el Archivo Histórico Nacional de Madrid y el Archivo General de Simancas, en sus secciones de Estado. Se ha manejado además correspondencia de representantes extranjeros, relacionados con estas colonias mercantiles y actas notariales y padrones de los archivos históricos provinciales de Madrid, Cádiz y Murcia. Se ba optado por una metodología orientada hacia la identificación de posiciones y discursos tanto por parte del gobierno español como de los propios extranjeros de las ciudades que enviaban sus representaciones a los órganos de poder central.

\footnotetext{
Ana Crespo Solana es Científica Titular del Instituto de Historia del CSIC. Dirección para correspondencia: C/ Albasanz,26-28, Madrid.E-mail:ana.crespo@cchs.csic.es

Vicente Montojo Montojo es Térnico Responsable del Archivo General de la Región de Murcia. Dirección para correspondencia: Dirección General del Libro, Archivos y Bibliotecas, Avenida de los Pinos, 4, 30009, Murcia.E-mail:vicente.montojo@carm.es

* Esta investigación se ha llevado a cabo en el marco del proyecto de investigación: «Naciones y Comunidades: perspectivas comparadas en la Europa Atlántica: 1650-1830», Plan Nacional I+D, 2006 HUM-01679/Ministerio de Ciencia e Innovación, dirigido por Ana Crespo Solana. Parte de la prospección documental de las colecciones sobre la Junta de Dependencias de Extranjeros y Junta de Comercio se está realizando dentro del Proyecto «Solo Madrid es corte» de la Comunidad de Madrid, S2007/HUM-0425, dirigido por José Martínez Millán.
} 
En síntesis las peticiones y quejas de los comerciantes y cónsules extranjeros demuestran la fuerza de unas comunidades que habían recibido grandes privilegios en la segunda mitad del siglo XVII y que fueron recibidas y atendidas por la Junta con bastantes consideraciones, de lo que se deduce una actitud conciliadora por parte del gobierno, y en el que influyeron no sólo estas reclamaciones sino también las presiones de los embajadores y las limitaciones de los tratados de paz. La Junta de Dependencias de Extranjeros, por lo tanto, asumió una política muy distinta a la de Comercio del reinado de Carlos II, que protegía el comercio español, y tendió a aceptar las peticiones de comerciantes de respeto a sus exenciones fiscales y costumbres relativas a su práctica mercantil, al tiempo que cabe plantear una concepción distinta de la comunidad extranjera, de la nación como corporación autocéfala, desligada del estado de su territorio de origen e influyente en la corte y sus camarillas.

Palabras Clave: Junta de Dependencias y Negocios de Extranjeros. Comunidades mercantiles extranjeras. Historia del comercio. Edad Moderna. Siglo XVIII. Instituciones.

\section{The 'JunTa de DePENDENCIAS DE EXTRAJEROS' (1714-1800): THE SOCIO-POLITICAL BACKGROUND OF A HISTORICAL INSTITUTION}

ABSTRACT: This paper sets out to analyze the Junta de Dependencia de Extranjeros, an institution that was created within the framework of the government reforms that characterized the reign of Phillip $V$ after the war of Spanish succession in order to monitor and control the activity of foreign merchants settled in numerous Spanish cities. During its operative period this institution developed a strong links and effective lines of communication with foreign merchant communities resident in Spain. This study is based on primary sources such as the documentation generated by the Junta, which included requests and complaints lodged by merchants and merchant communities as well as reports on the appointment of foreign consuls. These sources are preserved in the State sections of the Archivo Histórico Nacional de Madrid and the Archivo General de Simancas. The correspondence of the representatives of merchant communities in Spain has also been used, as well as affidavits and population censuses preserved in the Provincial Archives of Madrid, Cadiz and Murcia. These sources have been interrogated in order to establish the stances and discourses adopted by both the Spanish government and the foreign merchants settled in those cities that sent representatives to the offices of Spain's central government.

The requests and complaints filed by foreign merchants and consuls in this context demonstrate the strength of their communities, which had been granted substantial privileges during the second half of the seventeenth century, and to which the Junta responded with a high degree of understanding. The Junta's conciliatory stance was linked not only to pressure exerted by foreign ambassadors, but also to limitations established by the peace treaties signed by Spain. The Junta de Dependencia de Extranjeros clearly adopted a radically different position to that of Charles II's fiercely protectionist government, and generally responded favourably to requests from foreign merchants relating to tax exemptions and the defence of commercial practices. These foreign communities can be regarded as autonomous entities that were detached from their respective countries of origin and enjoyed a great deal of influence at the royal court and within its lobbies.

KEY WORDS: Junta de Dependencias y Negocios de Extranjeros. Foreign merchant communities. History of Commerce. Modern Age. Eighteenth century. Institutions. 


\section{INTRODUCCIÓN. LAS LEYES CONTRA EXTRANJEROS Y LA LUCHA POR LA REPRESENTACIÓN}

En un largo contexto histórico, la Corona española luchó contra el deterioro de la posición que España tenía en los mercados europeos y en los coloniales americanos, evidente ya desde la segunda mitad del siglo XVI ${ }^{1}$. Para los autores de la literatura económica de la época la razón principal de aquel deterioro se fundamentaba en el control paulatino que las redes de mercaderes extranjeros estaban alcanzando dentro de los circuitos financieros y económicos de la Monarquía Hispánica ${ }^{2}$. Esta idea, inspirada en unos claros sentimientos xenófobos, tenía sin embargo un fundamento real, inevitable y de naturaleza estructural: el propio Imperio español y su espectacular extensión había demandado la connivencia de financieros de todas las nacionalidades, prácticamente desde el mismo comienzo de su existencia. Sin recursos reales para financiar las empresas militares y navales fuera de la península ibérica, el gobierno de los Austrias experimentaba en realidad las mismas necesidades que todas las demás naciones mercantilistas y a medida que demandaba créditos para sostener el imperio, los mercaderes internacionales se organizaban para aceptar las enormes necesidades que la expansión europea exigía ${ }^{3}$. Pero además había otro hecho que servía de telón de fondo a esta realidad económica y política. España se convirtió en un territorio de acogida de inmigrantes procedentes de diversos orígenes europeos. Desde la Baja Edad media se había producido una oleada de diásporas, de salida y entrada de inmigrantes, en un contexto complejo y multifactorial contextualizado por las guerras, los conflictos religiosos, el aumento demográfico y el crecimiento económico de muchas regiones ${ }^{4}$. En realidad, esto era debido a cambios importantes en la propia configuración social y económica de Europa desde antes del siglo XV pero la propia expansión y el ensanchamiento de los horizontes económicos a partir de dicha centuria hizo mella en la idiosincrasia europea y la emigración se convirtió en un medio de supervivencia colectiva generador de nuevos oficios relacionados precisamente con el modelo de expansión marítima y comercial que la mayor parte de los países europeos estaban forjando. Así, desde el siglo XV se empezaron a formar nutridas colonias de mercaderes

${ }_{1}$ Casado Alonso, Hilario, «El comercio español en las rutas del Norte en la época de Carlos V», en: Carlos V: Europeísmo y universalidad (Congreso Internacional, Granada, 1-5 de mayo de 2000), Madrid, 2001, v. 4, págs. 129-158.

2 Lorenzo Sanz, Eufemio, Comercio de España con América en la época de Felipe II, Valladolid, 1986. 2 tomos.

3 RUIZ IBÁÑEZ, José Javier, «Bellum omnium contra omnes. Las posibilidades y contradicciones de la guerra económica por parte de la monarquía hispánica en la década de 1590», Studia Historica (Historia Moderna), 27 (2005), págs. 85-109.

${ }^{4}$ GonZÁlez JimÉnez, Manuel et al., Acogidos y rechazados en la historia, Valladolid, 2005. 
extranjeros en importantes ciudades españolas, muchos de ellos conectados fuertemente con las redes internacionales de financieros y mayoristas 5 .

Extranjeros y sociedad han sido, pues, temas paralelos en el estudio del conjunto de problemas de la situación de España en el ámbito europeo y mundial. Existe una bibliografía muy abundante para los siglos XVI y XVII aunque últimamente se están aportando trabajos sobre el XVIII que se caracterizan por la utilización de fuentes también extranjeras y no solo de carácter local ${ }^{6}$. El siglo XVIII supone, en general, un período de crisis y cambio económico y político y en el cual la situación, y también la percepción social, de las comunidades toca fondo debido al cruce de factores de diversas cuestiones. Un modelo de análisis viable es aquel que enfoque tres cuestiones entrelazadas y en las que aún no se ha profundizado en su mayor parte a la hora de abarcar el estudio de las comunidades mercantiles: cuantificación de la colonia (con fuentes documentales complementarias), el análisis socio-institucional con objeto de describir la capacidad de integración y conformación de la comunidad/nación, y la funcionalidad económica de un colectivo fuertemente arraigado en la sociedad y la economía española de la época y de cuyas actividades dependían amplios sectores de las finanzas, el comercio exterior, las manufacturas o la construcción naval. ${ }^{7}$ La Corona española, los estadistas e intelectuales, y la propia sociedad de la época, eran conscientes de esta realidad inevitable. De hecho, las leyes destinadas a controlar y vigilar y, en el fondo, minar las actividades económicas que los extranjeros estaban logrando cada vez más en muchas ciudades españolas relacionadas con la economía atlántica se remonta a las primeras décadas del reinado de Carlos I. A partir de 1648 y, sobre todo, a lo largo del siglo XVIII, las nuevas realidades diplomáticas abrieron un nuevo cauce de entendimiento entre la Monarquía Hispánica y sus rivales, las potencias marítimas europeas. Los armisticios y los acuerdos multilaterales ayudaron a que en España se creara una superestructura institucional que produjo que algunas comunidades extranjeras encontraran apoyo al amparo de leyes que las protegían en su estancia en España y en las actividades que desarrollaban. De hecho, la creación de la Junta de Dependencias de negocios extranjeros, en 1714, aun en su deseo de controlar la presencia real de foráneos (incluyendo vecinos y transeúntes) y el alcance de las actividades económicas que estos realizaban, rompió con una tradición anterior, instaurándose una nueva época de respeto

5 AlONSO GARCíA, David, «Entre Granada y Castilla. La familia Fuente y la hacienda real a comienzos de la Edad Moderna», Investigaciones Históricas, 25 (2005), págs. 11-30; ZYLBERBERG, Michel, Une si douce domination. Les milieux d'affaires français et l'Espagne vers 1780-1808, Paris, Cheff, 1993.

${ }^{6}$ Lario OÑate, María del Carmen, La colonia mercantil británica e irlandesa en Cádiz a finales del siglo XVIII, Cádiz, 2000.

7 Este modelo se expone en: CRESPO SOlANA, Ana, «Flandes y la expansión mercantil europea: Origen y naturaleza de una red Atlántica (siglos XV-XIX)», en: PÁZ-SÁNCHEZ, Manuel de (coord.), Flandes y Canarias. Nuestros orígenes nórdicos, Taller de Historia, ${ }^{\circ}$ 37, Tenerife, 2007, tomo 3, págs. 13-83. 
hacia las comunidades extranjeras, lo que provocó que se desempolvaran antiguos privilegios, fueros y competencias que las naciones habían logrado desde la década de 1580, cuando se inició la aceptación oficial por parte de la Corona del establecimiento de la red de consulados extranjeros en suelo hispano.

Con este artículo intentamos demostrar que los cambios en la administración borbónica y el desarrollo de esta Junta de Dependencias de Extranjeros fueron hechos que afectaron a la situación de los extranjeros, los cuales se vieron involucrados por el viraje institucional y jurídico de su propia situación como ciudadanos especiales de los reinos de España. A partir de 1714, la lucha entre esta Junta gubernamental (pues dependía de las Secretarías del Despa$\left(\mathrm{cho}^{8}\right.$ ) y los representantes de las comunidades reflejaba también que la Corona aún consideraba a los comerciantes no-españoles como una "quinta columna» del comercio europeo. No obstante, la realidad era que, poco a poco, los intereses de una buena parte de las colonias se estaban deslindando del comercio que hacían sus casas matrices. Contradicción y ambigüedad se convirtieron, pues, en dos características principales de las leyes que la administración borbónica resolvió contra los mercaderes ya que en el fondo los propios estadistas y la sociedad española reconocían el hecho de que amplios sectores de la economía española, en especial los relacionados con el comercio exterior, no podría continuar sin la connivencia de estos grupos no autóctonos, de quienes se recaudaban ingresos fiscales importantes?.

Las leyes que la administración española elaboró contra los extranjeros en suelo hispano tomaron más razón de ser desde los comienzos de la expansión española en el Atlántico. En retrospectiva, y hasta comienzos del siglo XVIII, la corona hacía una distinción entre extranjeros naturales de los estados súbditos de la Corona y los procedentes de países que no lo eran. Es por ello por lo que algunas colonias disfrutaban de ciertos privilegios concedidos por el Rey de España. Era el caso de los flamencos, de los procedentes de algunas regiones italianas (napolitanos, sicilianos y sardos), de los vasallos del Franco Condado hasta 1678 , de los portugueses entre 1580 a 1668 y de aquellos oriundos de estados aliados o feudatarios: genoveses, toscanos, milaneses, venecianos y alemanes de estados católicos $^{10}$. Aunque atravesaron diversas evoluciones al paso de distintas coyunturas históricas, y paralelamente a las propias líneas de

8 CRESPO SOlAnA, Ana, «Extranjeros en la corte: análisis de una dialéctica entre la administración borbónica y las comunidades mercantiles en España en la primera mitad del siglo XVIII», en: Bravo Lozano, Jesús (ed.), Espacios de Poder. Cortes, Ciudades y Villas (Actas del Congreso celebrado en la Residencia de La Cristalera, Universidad Autónoma, Madrid, octubre de 2001), Madrid, 2002, vol. 2, págs. 345-362.

9 No tanto el almojarifazgo de Indias muy reducido, como los derechos de aduana de Alicante y Valencia, o los derechos sobre las exportaciones de lana y barrilla en los puertos del Cantábrico y Cartagena. Montojo Montojo, Vicente, «El comercio de Alicante en los reinados de Felipe II y Felipe III. Una construcción desde la cooperación», Cuadernos de Historia Moderna, 32 (2007), págs. 81-105.

${ }^{10}$ Oliva Melgar, José María, El monopolio de Indias en el siglo XVII y la economía andaluza. La oportunidad que nunca existió, Huelva, 2004, pág. 75; Collado Villalta, Pedro, «El impacto 
de distintas coyunturas históricas, y paralelamente a las propias líneas de la política exterior de la Monarquía Hispánica, estas leyes tuvieron siempre una serie de objetivos comunes. Uno de los temas claves fue el control de sus actividades económicas en relación a los mercados americanos pues poco a poco se fue identificando la proliferación de los negocios de los extranjeros en suelo español con el deterioro de España en los mercados exteriores, especialmente los coloniales. Desde la época de Felipe IV se tomaron medidas que resultaron infructuosas, como los intentos de la Junta del Almirantazgo y veedores de comercio del conde-duque de Olivares, o uno de sus más claros antecedentes, la Junta de Comercio de 1623, así como en posteriores juntas especiales de las últimas décadas del siglo XVII interesadas en ocuparse de los problemas que se derivaban de las actividades comerciales de los súbditos ${ }^{11}$. Pero al mismo tiempo, los banqueros extranjeros se hicieron con la Hacienda Real (asentistas flamencos y genoveses aparte de los judíos), lo que muestra la intención ambigua de la Corona en apartarlos definitivamente de los entresijos de la Monarquía. En el fondo se reconocía y aceptaba la dependencia de ellos y así se demostró ya a mediados del siglo XVII, en relación a determinados suministros y sobre todo por la concesión de privilegios por Carlos II a las comunidades ${ }^{12}$.

\section{LA PRESENCIA Y LA INFLUENCIA EXTRANJERA EN LA CORTE}

Las capacidades de los extranjeros en la vida económica y social de los reinos de España han quedado claras. Pero, ¿qué influencia o poder real tenían los mercaderes extranjeros en asuntos de Estado o de decisiones político-económicas?

Recientemente se ha considerado que las comunidades extranjeras se contaban entre las fuerzas de la Monarquía Hispánica, en el sentido de que tanto sirvieron de instrumento diplomático, como fueron objeto a veces de la hispanofilia $^{13}$ : la tendencia natural a aceptar el liderazgo católico de España hasta 1635-1648, en el caso de una porción importante de los ligueurs franceses ${ }^{14}$, de

americano en la Bahía: la inmigración extranjera en Cádiz, 1709-1819», en: I Jornadas de Andalucía y América, La Rábida, 1981, tomo I, págs. 51-73.

11 Tema muy estudiado recientemente por Montojo Montojo, Vicente, «El comercio de Levante durante el valimiento del Conde-Duque de Olivares (1622-1643)», Revista de Historia Moderna, 24 (2006), págs. 459-486, y por AlLOZA APARICIO, Ángel, «Guerra económica y comercio europeo en España, 1624-1674. Las grandes represalias y la lucha contra el contrabando», Hispania, LXV/1, 219 (2005), págs. 227-280.

12 Herrero SÁnchez, Manuel, «La Monarquía Hispánica y las Comunidades Extranjeras. El espacio del comercio y del intercambio en Madrid y Cádiz en el siglo XVII», Torre de los Lujanes, 46 (2002), págs. 97-116.

13 RuIZ IbÁÑeZ, José Javier y Vicent, Bernard, Los siglos XVI-XVII (Política y sociedad). Madrid, 2007, págs. 35-39.

${ }_{14}$ Descimon, Robert, y RuIZ IbáÑez, José Javier, Les ligueurs de l'exil (Le refuge catholique français après 1594), Seyssel, 2005, págs. 111-114 y 253. 
los flamencos, en caso de la colonia de Cádiz, después de Utrecht, o de los ingleses e irlandeses católicos, estos últimos basculando hacia la protección francesa desde $1688^{15}$. En este caso, podían ser suministradores de información, como sucedió en el caso de los comerciantes ingleses de Alicante, que fueron los primeros que dieron a conocer la sublevación de los segadores catalanes y el asesinato del virrey Coloma, o como instrumentos en uno u otro sentido de las estrategias internacionales. Sin embargo, a principios del XVIII, en gran parte de la sociedad española imperaba sobre todo la desconfianza, debido a la tendencia de los mercaderes extranjeros a ejercer el contrabando y, sobre todo, tal como se ha demostrado, a desarrollar mecanismos económicos legales de simbiosis con la propia sociedad en la que se integraban con tal de poder comerciar de manera más o menos, y aparentemente, legal (como el uso del testaferro, su papel como financieros en negocios que conducían otros, a veces familiares españoles, etc. $)^{16}$.

Como ya sabemos, las colonias de mercaderes eran numerosas en las ciudades portuarias según se denota de algunas cifras que, aunque irregulares en tiempo y espacio, sí dan noticia de las dimensiones de estas colonias en el contexto general de la sociedad española de Antiguo Régimen (por ejemplo, 125 extranjeros en Cádiz en 1662; u 80 extranjeros en Alicante, en 1683-1684, etc., por citar algunas), sin embargo, la presencia de extranjeros en Madrid y en los entornos cercanos a la Corte y a los órganos de poder era algo menor ${ }^{17}$. La presencia extranjera en Madrid estaba muchas veces condicionada por la diplomacia con los países con los que la Monarquía tenía relaciones. Debido a que la forma de reclutamiento de la mayor parte de los empleados y oficiales

15 Pérez Tostado, Ígor, «Una política de 'conveniencia y piedad': el despliegue diplomático de la Monarquía hispánica en la confederación de Kilkenny y la transformación de las relaciones hiberno-hispanas», Cuadernos del Seminario Floridablanca, 6 (2005), págs. 163-185.

${ }_{16}$ Crespo Solana, Ana, «Dutch mercantile Networks and the Trade with the Hispanic Port Cities in the Atlantic (1648-1778)», en: HAUSBERger, Bernd y BöTTCHER, Nikoalus (eds.), Redes y comercio en el mundo ibérico, siglos XVI-XIX, Frankfurt a. M./Madrid, Iberoamericano de Berlín y El Colegio de México, Ed. Vervuert/Iberoamericana, 2009 (en prensa).

${ }_{17}$ La bibliografía sobre extranjeros en España se ha visto aumentada en la última década. Algunos trabajos son: OZANAM, Didier, «La colonie fraçaise de Cadiz au XVIIIe siècle, d'après un document inédit (1777)», Melanges de la Casa de Velázquez, II (1969), págs. 259-348; POITRENEAU, André, «La inmigración francesa en el reino de Valencia (siglos XVI-XIX)», Moneda y Crédito, 137 (1976), págs. 103-133; JARQue MARTíneZ, Encarnación y SAlAS Aussens, José Antonio, «Extranjeros en España en la segunda mitad del siglo XVIII», en: Coloquio Internacional Carlos III y su siglo, Madrid, 1990, págs. 985-997; Ramos Medina, María Dolores, «El origen de una élite negociante en Madrid: los mercaderes de Lonja en el siglo XVII», Espacio, Tiempo y Forma, serie 4, Historia Moderna, 14 (2001), págs. 349-375. Y, sobre todo, los nuevos enfoques que está teniendo esta línea historiográfica en: CRESPo SOLANA, Ana, Entre Cádiz y los Países Bajos. Una comunidad mercantil en la ciudad de la Ilustración, Cadiz, 2001; WeBER, Klaus, Deutsche Kaufleute im Atlantikhandel 1680-1830. Unternehmen und Familien in Hamburg, Cádiz und Bordeaux, München, C.H. Beck, cop., 2004; GARCía FERnÁNDEZ, Nélida, Comerciando con el enemigo: El tráfico mercantil anglo-español en el siglo XVIII (1700-1765), Madrid, CSIC, 2006. 
de los Consejos y Secretarías tenían perfil delimitado en cuanto a su procedencia social, así como la organización de estos cargos en relación a unas «familias administrativas», condicionados o derivados del sistema de patronazgo, había pocos extranjeros formando parte de las secretarías, juntas o consejos de Estado. ${ }^{18}$ No obstante, los ministros de la Monarquía estaban bien relacionados con los ministros extranjeros residentes en Madrid, tal como se especifica en un Manifiesto enviado en 1717 por el propio marqués de Grimaldo ${ }^{19}$.

Aparte de esta situación, la presencia de extranjeros en Madrid no era muy limitada, al menos subió el número de mercaderes residentes procedente de diversos orígenes durante los siglos XVII y XVIII. Según el Donativo de 1625, había 602 mercaderes con una generosa contribución. En 1757 había censados 887 y en 1804 llegaron a ser $1364^{20}$. Este crecimiento puede estar relacionado con la conversión de Madrid en capital financiera internacional. Según un recuento realizado con documentos notariales, durante los reinados de Felipe $\mathrm{V}$ y Fernando VI hicieron testamento o poder para testar en la ciudad un número aproximado de 261 extranjeros $^{21}$. En el siglo XVIII, y al contrario de lo que sí sucedía en otras ciudades, y según Mauro Hernández, apenas había representación extranjera en el cuerpo de regidores del Ayuntamiento de Madrid y ello a pesar de que a finales del siglo XVIII Madrid tenía la mayor densidad de grandes de España y titulados ${ }^{22}$. También un recuento de matrimonios hechos entre

18 Castro, Concepción de, «Las secretarías de los consejos, las de Estado y del Despacho y sus oficiales durante la primera mitad del siglo XVIII», Hispania, 201 (1999), págs. 193-215; LÓPEZCORDón, María Victoria, «La primera secretaría de Estado: la institución, los hombres y su entorno (1714-1833)», Revista de la Universidad Complutense, 2 (1980), págs. 15-44; PÉREZ-PRENDES Y MUÑOZ DE ARrACO, José Manuel, «Una visión de la administración central española en el siglo XVIII», Revista de la Facultad de Derecho de la Universidad de Madrid, 6 (1959), págs. 323-348; NAva RodrígueZ, Teresa, «Problemas y perspectivas de una historia social de la administración. Los Secretarios del Despacho en la España del siglo XVIII», Melanges de la Casa de Velásquez, 30/2 (1994), págs. 151-166; BARrios, Feliciano, El Consejo de Estado de la Monarquía Española, 15211812, Madrid, 1984; Álvarez Morales, Antonio, Historia de las instituciones españolas (ss. XVIIIXIX), Madrid, 1982.

19 Archivo Histórico Nacional Madrid (en adelante: AHNM) Estado 794, Libro 3. Copia del Manifiesto por el Marqués de Grimaldo, 1717.

20 Hernández, Mauro, A la Sombra de la Corona. Poder local y oligarquía urbana, Madrid 16061800, Madrid, 1995. págs. 11-17.

21 Archivo Histórico de Protocolos notariales de Madrid (en adelante: AHPNM), Testamentos y poderes para testar. Algunos de estos testamentos de extranjeros utilizados para esta investigación son los siguientes: Protocolos: 16.587, fol. 381; 17.986, fol. 14; 17.628, fol. 65; 19.910, fol. 872; 18.468, fol. 503; 17.616, fol. 144; 17.128, fol. 544; 18.192, fol. 957; 17.190, fol. 1515; 17.095, fol. $91 ; 20.298$, fol. $84 ; 15.940$, fol. $153 ; 19.548$, fol. $261 ; 16.286$, fol. 515; 14.636, fol. 118; 17.934, fol. 32; 18.335, fol. 120; 18.473, fol. 66; por citar algunos relevantes, casi todos pertenecientes a mercaderes y hombres de negocios de la Villa y Corte.

22 Hernández, Mauro, A la sombra..., págs. 3-8; Bermejo Cabrero, José Luis, Estudios sobre la administración central española (siglos XVII y XVIII), Madrid, 1982; EsCUDERO, José Antonio, Los Secretarios de Estado y del Despacho, 1474-1724, Madrid, 1969. 
1704 y 1713, señala que el 69’8\% de los cónyuges eran foráneos que residían en la capital. La proporción de forasteros subió de 3'9\% en 1704 hasta 20'5\% en 1714, según Carbajo Isla, para luego descender de nuevo ${ }^{23}$. Unas y otras cifras parecen contradictorias. La funcionalidad de estos en la villa y Corte es, no obstante, semejante a la que tenían en otras ciudades. David Ringrose hace un cotejo de Madrid y sus características demográficas con otras ciudades españolas pero no lo hace con las ciudades mercantiles. Solo cita a Barcelona, puerto comercial y manufacturero que también necesitaba de los inmigrantes para expandirse ${ }^{24}$. Cuando habla de los factores de la migración afirma que: «las migraciones siguen la red de las relaciones comerciales y de las comunicaciones, aprovechando la información existente, y los contactos personales, en la búsqueda de oportunidades en la ciudad». En el siglo XVII existían dos de tales redes en Madrid: «una seguiría las rutas que iban hacia las provincias costeras y que proporcionaban a Madrid las importaciones, los productos coloniales y los artículos de lujo de origen nacional» ${ }^{25}$. Señala que muchos emigrantes se dedicaron a las actividades mercantiles, sobre todo procedentes de otras provincias españolas, principalmente vascas y catalanas. Sin embargo, Madrid tenía ciertos handicaps para ser el centro de una red económica que se alargaba a las ciudades mercantiles de la periferia peninsular ${ }^{26}$. Sobre la salud económica de los extranjeros residentes en Madrid también hay disponibles algunos datos importantes. Según el «Repartimiento por servicio de milicias» de lo que tenían que pagar a la Corona los Gremios de Madrid entre los años 1683 y 1692, los mercaderes de lonja extranjeros debían pagar 27120 ducados, una suma mucho más elevada que lo que se les exigía al resto ${ }^{27}$. Ello se podía explicar, no obstante, por el hecho de que los extranjeros tuviesen que pagar más impuestos, ya que los Cinco Gremios Mayores actuaron muy unidos desde el siglo XVII para la defensa de sus intereses contra la competencia que les hacían los importadores de otras nacionalidades, razón de la creación, entre otras formas de representación jurídica, de unas Ordenanzas en 1741.

Aparte de esta presencia general de extranjeros en Madrid, también la propia Corte constituía un espacio cultural mestizo que atraía a extranjeros dedicados a los oficios intelectuales y científicos ${ }^{28}$. Es conocido como entre las cate-

${ }^{23}$ Carbajo IsLa, María F., La población de la villa de Madrid desde finales del siglo XVI hasta mediados del siglo XIX, Madrid, 1987, pág. 121.

24 RINGrose, David, Madrid y la economía española, 1560-1850, Madrid, 1985, pág. 75.

${ }_{25}$ Ringrose, David, Madrid y la economía..., pág. 75. Alicante y Madrid, por ejemplo, tenían una relación especial.

${ }^{26}$ Ringrose, David, Madrid y la economía..., pág. 14; Juliá DíAz, Santos, Ringrose, David, y Segura Graíño, Cristina, Madrid. Historia de una capital, Madrid, 1997, pág. 165.

27 Capella, Alfonso y Matilla Tascón, Antonio, Los Cinco Gremios Mayores de Madrid, Madrid, 1957, pág. 27. Según esto, el resto de los grupos y gremios correspondientes apenas llegaban a los 5000 ducados, a excepción de los maestros sastres que pagaron 8619 .

28 Aymard, Maurice y Romani, M.A. (dirs.), La Cour comme institution économique, Paris, 1998 ; 
gorías socio-profesionales había oficios muy considerados por los extranjeros, muchos de ellos participantes de una población flotante y transeúnte propia de los espacios cortesanos. Muchos extranjeros trabajaron en los espacios culturales y en la construcción de la ciudad. Por ejemplo, trabajaron en la construcción del Palacio y Jardines de Aranjuez para lo cual vinieron desde Flandes, especialmente entendidos en diques y jardinería, como Adrián Van der Muller, quien da una muestra de la influencia flamenca en Aranjuez, o desde la Alsacia alemana el escultor Nicolás de Bussy ${ }^{29}$. Su construcción exigió un costoso y vasto plan de construcción de diques, presas, estanques y canalizaciones. De Italia llegaron ingenieros y escultores ${ }^{30}$. Algunos de ellos llegaron dentro de los programas de contratación que llevó a cabo el gobierno de Felipe V, como el italiano Felipe Juvara y su discípulo Sachetti, empleados en las obras de reconstrucción del viejo Alcázar, incendiado en 173431. También las Reales Academias, fundadas en 1713 (de Lengua), en 1738 (Historia) y en 1744 (Bellas Artes de San Fernando) contaron con la participación de extranjeros.

Pero, minoritarios o no, ¿eran realmente influyentes? Había sectores en los que la influencia de los mercaderes extranjeros sí se hacía notar, como en la economía y en las finanzas. A principios del XVIII se intentó incluso que los franceses monopolizasen la exportación de lana, en sustitución de los holande$\operatorname{ses}^{32}$. También tenían representación, sea directa o indirecta, en la administración (sobre todo si afectaba a su identidad y a los modos de su inserción en la sociedad española) y en cuestiones de política exterior. Esta influencia no siempre fue directa ya que la presencia de extranjeros en los propios órganos de decisión era pequeña. Algunos, muy pocos, llegaron a ser componentes de la administración, sobre todo en las Juntas especiales que se crearon para temas concretos. Esta presencia se daba desde la segunda mitad del siglo XVII ${ }^{33}$. Hasta el momento no se ha visto clara la relación entre ellos y los representantes de las comunidades mercantiles de las ciudades. Por otra parte, una buena parte de la política económica española parecía pendiente de un obseso afán de apartar a los extranjeros de las actividades económicas, o de evitar su compe-

Guerra, R. La Corte española del siglo XVIII, Madrid, 1991; Norbert, Elias, La sociedad cortesana, México, 1982; Martínez Millán, José, «La Corte de la Monarquía Hispánica», Studia Historica (Historia Moderna), 28 (2006), págs. 17-61.

29 SánCHeZ-Rojas FenOl, María del Carmen et al., Nicolás de Bussy. Un escultor europeo en España (Tercer centenario de su muerte 1706-2006), Murcia, 2006.

${ }^{30}$ Lafuente, Antonio, Guía del Madrid Científico. Ciencia y Corte, Madrid, 1998, pág. 62.

31 Lafuente, Antonio, Guía del Madrid Científico..., pág. 138.

32 SANZ AYÁn, Carmen, «Financieros holandeses de Felipe V en la Guerra de Sucesión: Huberto Hubrecht», en: CreSpo Solana, Ana y Herrero SÁnCHEZ, Manuel, (coords.), España y las 17 provincias de los Paises Bajos: Una revisión historiográfica, Córdoba, 2002, v. 2, págs. 563-582.

33 DeDieU, Jean Pierre, «Un instrumento para la historia social: la base de datos Ozanam», Cuadernos de Historia Moderna, 24 (2000), págs. 185-205; MAuPERAS, Arnaud, Boulant, Antoine et al., Les Ministres et les ministères du Siècle des Lumières (1715-1789), Etude et dictionnaire, Paris, 1996; FAYARD, Jeannin, Los miembros del Consejo de Castilla (1621-1746), Madrid, 1982. 
tencia como en el caso de la seda china, cuando paradójicamente también se daban casos de intentos de inclusión de estos y de su parecer en los asuntos de las secretarías, consejos y juntas. En determinadas épocas fueron más influyentes por diversas razones de clientelismo político, como en el caso de Orry, Grimaldo, Alberoni o el marqués de la Ensenada, quienes formaron a su alrededor largas redes profrancesa o proitaliana. El propio A. Baudrillart afirmaba que Ensenada era un agente francés, o el partido en torno al ministro Carvajal (filobritánico), colaborador de Ricardo Wall. Durante el reinado pacifista de Fernando VI, el gobierno estuvo, al parecer, aún más abierto a la entrada de ideas extranjeras $^{34}$. Sin duda, la circulación de tales ideas en los espacios cortesanos, la presencia de estos en la ciudad así como sus representaciones en las juntas y secretarías, hizo que desde la Corona se demostrase un interés por sus actividades.

Por ejemplo, Felipe V había mandado una circular a las ciudades para que se averiguasen las causas del atraso en que se hallaba España en cuestión de manufacturas y tráfico mercantil y proponer remedios. Al parecer, la orden fue propuesta por el monarca francés para reanudar las relaciones comerciales de España con Francia, evitando competencias y rivalidades. Se encargó al ministro Jean Orry que formara una junta para estudiar los diversos proyectos que se presentaran y se comisionó a Gaspar Naranjo, autor de Restablecimiento del comercio y las fábricas de España para que visitara las provincias y ajustara con los mejores fabricantes la provisión de paños para vestuario de la tropa, fracasando en este intento debido a las intrigas de los proveedores habituales. En su informe sobre los diversos ramos de que componen el comercio y las fábricas ${ }^{35}$ expone como en realidad la economía política se tambaleaba entre fuertes competencias internas representadas por los diferentes «partidos» a los que no eran ajenas las propias luchas entre las colonias de mercaderes y sus capacidades respectivas de acceder a las influencias de la Corte. Solo así se entiende por qué en una época en la que la Corona luchaba contra la perniciosa presencia extranjera, en la Corte se recibían memoriales y discursos de mercaderes extranjeros que podían también influir en la política económica borbónica. Ello también está relacionado con el hecho de que apenas conocemos nada de la política económica del siglo XVIII y que la paternidad de muchas ideas que luego se llevaron a la práctica atendían a presiones que circulaban también entre los especializados mercaderes extranjeros residentes en muchas ciudades

${ }^{34}$ Cit. en Gómez URdáÑEZ, José Luis, El proyecto reformista de Ensenada, Lleida, La Rioja, 1996, págs. 67 ss.

35 AHNM Estado, leg. 3188, expt. 383. Citado en LEÓN Tello, Pilar, Un siglo de fomento español (años 1725-1825). Expedientes conservados en el Archivo Histórico Nacional de Madrid, Madrid, 1980. «Memoriales de Naranjo sin nombre de la persona a quien la dirige, sobre la impresión de sus cinco libros, proponiendo como lugar Córdoba en donde había mejores imprentas que en Madrid y se podía hacer con mayor sigilo, pedía como compensación a sus trabajos que se concediera a un hijo suyo una pensión sobre el obispado de Córdoba y un título de Castilla en blanco cuyos beneficios disfrutaría el obispo de esta ciudad que podía ser el encargado de la edición», s.f. 
españolas. Antonio Miguel Bernal afirmaba que existe aún un gran desconocimiento sobre la evolución y génesis del pensamiento económico español en relación, sobre todo, a cuestiones coloniales. El hecho de que una buena parte de las obras circularan censuradas y sean desconocidas, o la duda sobre la verdadera autoría de muchos textos económico-políticos de la época (como es el caso del Nuevo Sistema de Campillo) ponen en evidencia la necesidad de hacer un estudio comparativo con las corrientes de pensamiento económico en otros países mercantilistas en estos años básicamente de transición entre el mercantilismo y el liberalismo ${ }^{36}$. Algunas ideas que se plasmarán de forma común en muchos de estos escritos llegaron de Europa y estaban en circulación, como la eficacia de los modelos coloniales, cuestionados a partir de la mitad del siglo XVII, cuando se hace evidente que ni la afluencia de metales monetarios ni la expansión colonial eran equivalentes a progreso económico. En este momento se empiezan a definir las posibilidades económicas de las colonias en cuanto a productoras de materias primas y como mercados en expansión para la producción nacional manufacturera. Este esquema, que era bastante perjudicial para el caso español, especialmente, fue criticado por algunos tratadistas europeos y también se reflejó en las propuestas de ciertos memorialistas ${ }^{37}$.

\section{La Junta de Dependencias de Extranjeros: vista desde la Pers- PECTIVA SOCIO-INSTITUCIONAL}

La creación y desarrollo de la Junta de Dependencias de Extranjeros debería ser objeto de un tipo de análisis según el modelo clásico llevado a cabo por Pere Molas Ribalta, desde el punto de vista de la historia social de las instituciones $^{38}$. Por el momento se dispone de mucha documentación que está siendo procesada por los autores de este artículo. Las normas y costumbres que dieron lugar a la formación de juntas especializadas han sido tratadas en la historiografía modernista ${ }^{39}$. En un principio, la creación de la Junta de Dependencias

36 Bernal, Antonio Miguel, «De colonias a Repúblicas: España-América (siglos XVIII-XIX). Reformismo, libre comercio y crecimiento económico», en: FONTANA, Joseph, Historia y proyecto social. Jornadas de Debate del Institut Universitari d'História Jaume Vicens Vives, Barcelona, 2004, págs. 103-148, cfr. 121.

37 Idea expresada en Bernal, Antonio Miguel, España, proyecto inacabado. Costes/beneficios del Imperio, Madrid, 2005. En el caso español, las críticas se agudizaron en el siglo XVIII cuando se pusieron en entredicho los posibles beneficios del monopolio estatal en régimen colonial. Las colonias sólo servían para proporcionar materias primas a cambio de mercados para las manufacturas. A mayor grado de monopolio mayor coste que disminuía los beneficios adicionales.

38 Amelang, James, «La historia social de la España Moderna: seis consideraciones», Manuscrits, 8 (1990), págs. 71-86.

39 Prado Rozas, Antonio, Reglas para oficiales de secretarías y catálogo de las secretarías del Despacho y del Consejo de Estado que ha habido desde los señores Reyes Católicos hasta el presente, junto con las plantas dadas a las secretarías, Madrid, 1755. 
de Extranjeros como una junta especial está intrínsecamente relacionada con la formación, a finales del siglo XVII, de la Junta General de Comercio de 1679, que se convocó con claros fines de lucha xenófoba tal como se indica en su orden de inicio. La Junta de Comercio se erigió

«con el firme propósito de fomentar y proteger la industria nacional y mejorar sus productos hasta el punto de poder desterrar de nuestro mercado principalmente del americano la plaga de géneros extranjeros» ${ }^{40}$.

No obstante, posteriormente la Junta de Dependencias de Extranjeros rompió la dinámica de estas juntas anteriores, incluyendo las Juntas de Contrabando que se dirigían ya a fomentar el comercio nacional español o a perseguir el fraude fiscal. En realidad, sería el cambio dinástico lo que pudo producir esta mutación de perspectiva por parte de la administración española.

En algunas de las juntas del siglo XVII, como la citada Junta de Comercio de 1623 o la Junta de Reformación, empezaron a analizarse proyectos que denunciaban la cada vez mayor presencia de extranjeros en las actividades económicas españolas y, sobre todo, en el comercio de Indias ${ }^{41}$. Aquello obedecía a un contexto de conflicto permanente con el exterior, los cuales se habían agudizado a partir del fin de la Tregua con los holandeses en 1621 y la promulgación de los embargos de la Corona a los extranjeros. Ello pareció producir cierto cambio de actitud de los extranjeros que se vieron perjudicados por las amenazas de embargos y daños a sus personas y bienes. Se sintieron, de alguna manera, «invitados» u obligados a representar sus intereses ante la Corte y ante las juntas. La creación del Almirantazgo de los Países Septentrionales en Sevilla en 1624 fue, de alguna manera, un éxito de las iniciativas mercantiles privadas y extranjeras (estuvo temporalmente liderado por mercaderes flamencos y alemanes andaluces) por preservar su integridad y sus intereses económicos ante las agresivas políticas imperiales. Pretendía dejar claro que los negocios flamencos estaban muy apartados de los servicios, y sobre todo del transporte holandés, lo cual no era cierto. ${ }^{42}$ Estructuralmente, la economía española dependía ya entonces de las redes internacionales de comercio que habían generado sus propios mecanismos de mantenimiento.

Las juntas del siglo XVII tuvieron una corta vida, empeñada en la solución rápida y vana de problemas que no eran nada coyunturales sino que necesitaban cambios orgánicos a nivel de Estado. Por su parte, la Junta de Dependencias de Extranjeros tuvo una larga evolución entre principios del siglo XVIII y

40 Cit. en Capella, Alfonso y Matilla Tascón, Antonio, Los Cinco Gremios..., pág. 133.

41 Alloza Aparicio, Ángel y CÁRCEles de GeA, Beatriz, Comercio y riqueza en el siglo XVII. (Cultura, política y pensamiento económico), Madrid, CSIC, (en prensa).

42 La Junta del Almirantazgo fue creada en Madrid para luchar contra el contrabando. Alloza Aparicio, Ángel, Europa en el mercado español. Mercaderes, represalias y contrabando en el siglo XVII, Madrid, 2006. 
comienzos del XIX ${ }^{43}$. Se trataba de una junta gubernamental, creada en 1714 con la intención de vigilar los negocios extranjeros en puertos españoles ${ }^{44}$. Vio cientos de asuntos relativos a nombramientos de cónsules, delegados y jueces conservadores de las naciones extranjeras, aunque con ello no lograra del todo su cometido, controlar las actividades de los no-naturalizados, en vista de las abundantes memorias sobre problemas comerciales que registró ${ }^{45}$. Estaba compuesta por algunos de los miembros de las propias secretarías del Despacho como Bernardo Duro del Saz, marqués de Villarias, Juan Elizondo, su secretario, o el mismo Juan Bautista de Orendayn, que fue presidente de la Junta de Dependencias en 172446. La Junta de Dependencias de Extranjeros fue creada para controlar los negocios extranjeros e informar al rey de la marcha de los mismos. José Hidalgo González, en su memoria histórica publicada en 1806 describe algunas modificaciones en la forma de distribución de las salas de corte durante el reinado de Felipe III como un remoto antecedente de esta Junta, ya en 1608. Así, se discutía en las salas del Consejo de Estado algunos asuntos de los negocios extranjeros que afectaban directamente a los asuntos de Estado. La consolidación de una junta especial en 1714 atiende a la práctica de organizar «negociaciones perpetuas» sobre determinados asuntos ${ }^{47}$. La razón principal de la constitución de la junta fue, según el autor anónimo del libro-índice localizado junto a los despachos de la Secretaría de Dependencias y negocios de Extranjeros, el «examen y despacho de las dependencias de los franceses» ${ }^{48}$. Muy pronto, la Junta aglutinó competencias referentes a cuestiones, declaraciones, peticiones, negocios fraudulentos, problemas con la justicia y con la jurisdicción de cónsules y jueces conservadores relacionados con las principales colonias de nacionales esparcidos por la geografía española.

Las prerrogativas de la Junta de Dependencias de Extranjeros se articuló en torno a los siguientes aspectos: En primer lugar, controló los nombramientos de cónsules y otros representantes, sobre todo, de jueces conservadores. Esta

43 Existe un registro en AHNM Estado, Libro 222.

${ }^{4}$ Hidalgo GonzÁlez, José, Historia de las Dependencias de Extranjeros y Colección íntegra de los Reales Decretos, Resoluciones, Ordenes y Reglamentos que por punto general se han expedido para su gobierno y otras providencias que se hallaban incorporadas al Cuerpo de la Legislación, Madrid, 1806, 3 vols., Archivo Histórico del Ministerio de Asuntos Exteriores; LARrugA, Eugenio de, Memorias políticas y económicas sobre los frutos, comercio, jarcias y minas de España, Madrid, 1787-1800, ed. facsímil, Zaragoza, 1995, vol. II, tomos IV, V, VI; describe la Real Junta de Dependencias de Extranjeros y su posterior agregación a la de Comercio, Moneda y Minas, pág. 259; LARrugA, Eugenio de, Historia de la Real Junta de Comercio, Moneda y Minas, Madrid, 1798, cap. III, Mss. en el Archivo del Ministerio de Hacienda, Madrid.

45 AHNM Estado, Libro 683.

46 AHNM Estado, leg. 605, exp.12 y 13, 4 de mayo de 1724.

47 Hidalgo González, José, Historia de las Dependencias..., t. 1, Notas y prólogo, s.f.

${ }^{48}$ Las series completas de estas fuentes se encuentran divididas, y en muchos casos copiadas, entre dos archivos: el AHNM Estado, Libro 683 y Libros 222 y 229, así como diversos legajos, y el Archivo General de Simancas (en adelante AGS) Estado, legajos 7582-7604. 
última es una figura poco estudiada pero muy importante para comprender la evolución del peso que los intereses extranjeros tenían en relación con algunas facetas de la política, la economía y la sociedad española en general ${ }^{49}$. Además, vigilaba que los extranjeros vecinos y transeúntes disfrutaran de los privilegios que tenían gracias a las relaciones diplomáticas que la Corona española tenía con otras naciones. También se ocupaba de las cuestiones fiscales, relacionadas con los impuestos y donativos que los mercaderes extranjeros otorgaban a la administración española en algunos momentos claves, o de la resistencia de los comerciantes a la introducción de la alcabala y el equivalente en el reino de Valencia ${ }^{50}$. La Junta también se preocupó de que la Corona promulgara, como de hecho hizo, algunas leyes con un carácter esencialmente pragmático, pues en ocasiones sirvieron - en palabras de Collado Villalta- para incorporar la mano de obra cualificada de la inmigración europea y clarificar, al menos legalmente, la situación residencial de los extranjeros a los que se consideraban como vecinos de los lugares donde habitaban. Es por esta razón por lo que las matrículas de extranjeros proliferaron a lo largo del siglo XVIII, a partir de unas disposiciones legales de $1716^{51}$.

Con todo, la situación de los extranjeros se vio principalmente afectada en la práctica porque esta Junta de Dependencias se convirtió en una plataforma para la reivindicación de antiguos privilegios que las diferentes naciones tenían en suelo hispano desde los orígenes de su establecimiento (secreto de sus libros contables, testamentarías). Al mismo tiempo también incidió, aunque en menor medida, en la apertura de un proceso caracterizado por el deseo de censar y cuantificar a la población extranjera, aunque los resultados de los distintos padrones y censos elaborados a lo largo de la centuria disten mucho de reflejar la verdadera población foránea de las ciudades españolas ${ }^{52}$.

En relación a los privilegios de las comunidades, las representaciones enviadas por sus portavoces reivindican un reconocimiento de la legitimidad del poder de la Corona de la cual eran súbditos y ciudadanos especiales, gracias a que las comunidades también estaban sometidas a unos fueros y prácticas locales $^{53}$. En realidad, la reivindicación de la identidad no está tampoco lejos de posibles intereses político-económicos. Las corporaciones constituían una base importante en la sociedad de Antiguo Régimen en España y en Europa, y esta-

${ }_{49}$ AHNM Estado, Libros 222 y 223 (Registros de las consultas de la Junta de Dependencias de Extranjeros) y Estado, Libro 683.

50 GiMÉNEZ LÓPEZ, Enrique, «Los problemas económicos del siglo XVIII. La acción política del humanista Felipe Bolifón», en: Mayans y la Ilustración (Simposio Internacional en el Bicentenario de la muerte de Gregorio Mayans. Valencia-Oliva 30 sept.-2 oct.), Valencia, 1990, T. 2., págs. 613-626. [Gregorio Mayans digital]

51 Algunas de estas matrículas, como la de 1764, están en AHNM Estado, leg. 629, expedientes 1, 2 y 3; Collado Villalta, Pedro, «El impacto americano...», pág. 54.

52 JaRque MartíneZ, Encarna y SAlas Aussens, José A., «Extranjeros...», págs. 985-997.

53 Juliá Díaz, Santos, Ringrose, David y Segura, Cristina, Madrid ..., pág. 167. 
ban extendidas a todos los sectores sociales y a todas las categorías socioprofesionales desde la Edad Media. Las corporaciones eran necesarias en una sociedad de Antiguo régimen, donde, su estamentalidad (como afirmaba Vicente Montojo) «supuso la existencia de una jerarquía y un corporativismo en el medio mercantil» 54 .

Los mercaderes hacían valer sus derechos a través de distintas organizaciones mercantiles. Pero al mismo tiempo, siempre se han utilizado diversos conceptos a la hora de tratar a las comunidades extranjeras, como colonia y nación, dos categorías aún no totalmente definidas a pesar de algunas aclaraciones recientes $^{55}$. Aparte de los consulados, ya analizados, había otras corporaciones o formas de asociacionismo que eran más comunes en algunas colonias, como las cofradías de mercaderes, los gremios, asociaciones, o compañías privadas o generales de comercio. Podría decirse que las cofradías o patronatos funcionaban también como un "paso previo y factor cohesionador»" Se tienen indicios de que en algunos casos aparecieron en época anterior a los propios consulados y sus cónsules. Tenían un santo patrón propio de cada nacionalidad: los franceses tenían a San Luis; los flamencos a San Andrés; los genoveses a San Jorge; los irlandeses a San Patricio; los portugueses a San Antonio, etc. También existían varios nombres referidos a los representantes de las comunidades. Sin embargo, nuestra primera pregunta hace referencia a si todos o algunos de estos representantes estaban realmente identificados con el sentir general de la comunidad mercantil extranjera o simplemente actuaban en nombre de unos intereses privados o de un sector concreto (casi siempre la élite) de la comunidad. Los nombres de los cargos que aparecen son los siguientes: mayordomo o diputado de la nación, juez conservador, juntas de comercio (privadas y no a nivel político), vicecónsul, o comisario.

Las políticas para el control del comercio que hacían los extranjeros afectaron a unas ciudades portuarias más que a otras, como fue el caso de la ciudad de Cádiz, donde las reformas orientadas a reforzar los órganos administrativos del monopolio hispano con América (Casa de la Contratación y consulado de mercaderes), estuvieron muy relacionadas con algunas de las leyes destinadas a vigilar y reglamentar las prácticas comerciales de los extranjeros y los hijos de éstos ya nacidos en la ciudad y que en la terminología de la época se llamaron «jenízaros». En 1720 se inició un interesante pleito entre estos (hijos de extranjeros nacidos en España) y el Consulado de mercaderes de la ciudad. Este pleito iniciado por el consulado de mercaderes autóctonos de Cádiz se desarrolló entre 1721 y 1726, finalizando con una real ejecutoria de 14 de febrero de dicho año que no sólo reconocía la españolidad de los hijos de extranjeros sino que tam-

${ }_{54}$ Montojo Montojo, Vicente, «Crecimiento mercantil y desarrollo corporativo en España: los consulados extraterritoriales extranjeros (ss. XVI-XVII)», Anuario de Historia del Derecho Español, LXI (1992), págs. 47-67.

55 Crespo Solana, Ana, «Flandes...», págs. 50 y ss.

56 Montojo Montojo, Vicente, «Crecimiento mercantil...», pág. 48. 
bién les otorgaba derechos a comerciar con América dentro de unos presupuestos. Los problemas y la xenofobia de los mercaderes españoles, no obstante, alargaron el pleito hasta 1752 con el apoyo de varios ministros españoles, sobre todo de José Patiño ${ }^{57}$. Podría decirse que ante la imposibilidad de la Corona de impedir las actividades de los mercaderes extranjeros, muy arraigadas ya en la sociedad española, las autoridades de la Casa de la Contratación pretenderán dos cosas principalmente: controlar y gravar los negocios de exportación de los extranjeros que cargaban en las flotas y galeones, e impedir la participación de mercaderes no avecindados o naturalizados ${ }^{58}$.

Además, proliferaron una serie de normativas para el control del apresto portuario con objeto de impedir una de las prácticas más frecuentadas por los mercaderes extranjeros: la introducción de buques procedentes de puertos norte-europeos tras un cambio de nombre del buque, en las propias flotas españolas con destinos a los puertos de la América hispana. Por ejemplo, una hipótesis digna de tener en cuenta es el hecho más que posible de que una de las razones del espectacular crecimiento del comercio de Cádiz a partir de 1717 y, sobre todo, a partir de la introducción de los navíos de Registro, en 1740, fuera debido al aumento de las actividades de los mercaderes extranjeros y de los hijos de éstos. Sin embargo, las leyes que se tomaron en el siglo XVIII muchas veces iban en contradicción con algunas políticas seguidas por Felipe $\mathrm{V}$ y Fernando VI como las que incluían la importación de obreros especializados de países de Europa. Franceses y flamencos fueron los que más vinieron. Estos obreros especializados extranjeros también disfrutaban de ciertos tipos de privilegios. Por ejemplo, en la Fábrica de seda y telares de Valencia, los artífices extranjeros (maestros y fabricantes) tenían una serie de privilegios. Uno de ellos era que gozaban de franquicia y libertad de entrada de los comestibles. Se les ayudaba a establecerse para que enseñaran sus artes a los naturales del país. Podían comprar bienes raíces en la ciudad y reino donde se asentaran; se les eximía de derechos e impuestos municipales y de alcabalas. Si en diez años el negocio daba la prosperidad esperada la Corona les otorgaría privilegio y goce de nobleza para él y sus descendientes. Debían pasar una estancia en la Corte con el fin de conocer las modas y saber así que géneros debían fabricar ${ }^{59}$.

Con el tiempo, el devenir histórico de la Junta se reflejó en varios intentos fallidos y unos pocos resultados coyunturales y esparcidos por la geografía española, y por cada colonia, con objeto de avivar la industria y el comercio nacional. Esta institución que controlaba, pero a la vez protegía los intereses de las colonias extranjeras también se vio influida por la xenofobia existente en

57 García-MaUriño Mundo, Margarita, La pugna entre el Consulado de Cádiz y los jenízaros por las exportaciones a Indias (1720-1765), Sevilla, 1999.

58 Ruiz Rivera, Julián Bautista, «Patiño y la reforma del Consulado de Cádiz en 1729», Temas Americanistas, 5 (1985), págs. 16-21.

59 Vidal Galache, Florentina y Benicia, Historia del Hospital de San Andrés de los Flamencos, 1594-1994, Madrid, 1996. 
algunos colectivos sociales. En el reinado de Carlos III, Juan de Los Heros Fernández, diputado director de los Cinco Gremios afirmaba que:

«Las guerras tan continuadas que sufrió España y los implacables celos de las naciones extrañaron el comercio de nuestra Patria. Los tratados de Paces, las alianzas, todo era animado del espíritu del comercio. Cesaron las fábricas en España, se adormecieron las artes y fue la pobreza sucesora de la prosperidad cuando principiaron los extranjeros a aprovisionarnos con sus mercancías» ${ }^{60}$.

Al igual que los Cinco Gremios Mayores de Madrid, muchas firmas de negocios y corporaciones españolas tenían, aunque solo fuera de giro, negocios en las principales capitales financieras europeas, abriendo incluso sucursales y factorías propias en las capitales comerciales europeas.

\section{LOS MEMORIALES DE EXTRANJEROS Y LA DEFENSA DE LA IDENTIDAD}

Dos de las cuestiones más tratadas en la Junta hacían referencia a la reivindicación de los privilegios como ciudadanos especiales acogidos a un fuero determinado y la defensa de los bienes y mercancías que llegaban a puertos españoles en navíos consignados a negociantes extranjeros. En muchas ocasiones, en aquellas ciudades donde abundaban las colonias extranjeras, estas dos cuestiones estaban intrínsecamente relacionadas. Los problemas que el trasiego portuario podía acarrear y la posible vulnerabilidad que los mercaderes podían experimentar ante los funcionarios y oficiales de las aduanas derivaban en la puesta en marcha de unos mecanismos de defensa que iban desde la cooperación al margen de las instituciones hasta la búsqueda de unas formas de autorrepresentación ante las autoridades.

Lo cierto es que en tiempos de guerra la cooperación entre mercaderes de distintas nacionalidades estaba muy por encima de las leyes contra ellos. Existen muchos casos de expedientes relativos a problemas que se originaban en las ciudades portuarias españolas con motivo de conflictos bélicos en donde se traslucen estos tipos de cooperación. Esto se daba más dependiendo de las nacionalidades de los participantes y las costumbres de relación diplomática que pudiese haber entre los países de origen. Por ejemplo, en 1725, con motivo de la guerra con Argelia, una barca holandesa, apresada por corsarios berberiscos naufragó en la bahía de Gibraltar. Su gobernador la socorrió ya que la embarcación llevaba un importante cargamento de madera para construcción de barcos, para la Armada española ${ }^{61}$. Este tipo de problemas eran comunes en las ciudades portuarias de Andalucía y Levante donde se daban muchos litigios por presas de naví-

60 Capella, Alfonso y Matilla Tascón, Antonio, Los Cinco Gremios..., págs. 69 y 271-273.

${ }^{61}$ AHNM Estado leg. 536. Expediente de 1725. 
os que llegaban a puertos de arribadas diferentes de los que aparecían en los contratos de fletamento de la firma ${ }^{62}$.

Pero algunos de los problemas más acuciantes eran los de la defensa de la identidad y la posición, algo que afectaba más a algunas colonias que a otras. En la Junta se vieron algunas consultas relacionadas con una instancia que hizo el mayordomo de la nación flamenca, en nombre de sus componentes, en relación a que se confirmasen los privilegios que gozaban por reales cédulas ${ }^{63}$. Si en el periodo 1702-1748 los ingleses y holandeses fueron constante objeto de represalias, por contraste franceses y genoveses disputaron su posición, pretendiendo los primeros que la suya fuera mejor aprovechando las nuevas relaciones de ambas coronas, francesa y española. Los genoveses le hicieron, no obstante, una dura competencia ${ }^{64}$. Uno de los pleitos más largos y, al menos, más claro en lo referente a la forma en la que se representó, fue la reivindicación de los privilegios de los ciudadanos flamencos que pretendían se les reconociese una vieja condición de «ciudadanía hispano-flamenca» tras el paso de los Países Bajos meridionales a la órbita imperial tras el Tratado de Utrecht. Esta condición fue solicitada por activa y por pasiva por los representantes de la comunidad, dividida internamente ante este hecho, y hasta por las autoridades de Cádiz, según se difiere de una consulta original del 12 de junio de 1729, de un oficio del embajador de Alemania y del gobernador de Cádiz, sobre las pretensiones de «unos alemanes y flamencos residentes en aquella ciudad» ${ }^{65}$. En esta representación se describía un concepto ambiguo: «ley y fuero de extranjeros en España», término que aparece así en los documentos de la propia época y al cual se acogía todo aquel extranjero que se veía en dificultades con las justicias españolas. Por ejemplo, en 1723, el capitán del buque Lilledael, procedente de Holanda, fue preso en la cárcel de Cádiz acusado de malversación. El vicecónsul Antonio Borges, medió por él ante las autoridades españolas esgrimiendo precisamente el «fuero» que le protegía por ser extranjero y encontrarse lejos de su patria y leyes ${ }^{66}$. También para los ingleses asentados en Canarias la figura del juez conservador constituía un derecho ratificado con la Paz de Utrecht de 1713 y era algo intrínsecamente unido a los privilegios ofrecidos por el tratado de comercio incluido en la misma paz ${ }^{67}$. En 1716, los banqueros ingleses de Sevilla tenían facultad para nombrar juez conservador ${ }^{68}$.

\footnotetext{
62 AHNM Estado leg. 641.

63 AHNM Estado leg. 641, Expt. 716, 17 de noviembre de 1727.

${ }^{64}$ Una prueba de ello es que la documentación de la junta da testimonio de que los genoveses tenían una tradición más antigua de alianza con España, a la que prestaron apoyo financiero y naviero desde 1519 y 1528; o lo mismo los venecianos, desde 1538 .

65 AHNM Estado leg. 620 (2), Expt. 761.12 de junio de 1729.

66 Archivo Histórico Provincial de Cádiz (AHPC), protocolos notariales (p.n.), n. 5/996, fol. 77r y v.

67 AGS. Secretaría de Estado, leg. 6824. Según Robert Sutton, Barón de Lexington, embajador y plenipotenciario inglés en Utrecht en 1712 y 1713.

68 AGS. Secretaría de Estado, leg. 6833.
} 
Otra cuestión diferente, pero también relacionada con la autorrepresentación de una comunidad, eran los nombramientos de cónsules y sus funciones. Pero la aparición de consulados en las ciudades españoles representa un problema muy versátil, que dependía de una variedad de casos concretos. Aquellas ciudades caracterizadas por una mayor afluencia, vía marítima generalmente, de barcos y mercancías, fueron las pioneras en el establecimiento de consulados. Pero hay que tener en cuenta un hecho importante, y es que el término consulado no es sinónimo de nación mercantil. Hay una diferencia que sería necesario matizar. El consulado es un órgano impuesto, en cierta manera, por la administración. Además del origen no muy claro de sus establecimientos, tampoco se sabe con certeza cuál era su exacta jurisdicción territorial, algo importante sobre todo en el caso de las colonias de extranjeros pues esta falta de exactitud provocaba problemas en lo concerniente a la jurisdicción comercial en algunos puertos, sobre todo en los secundarios. Crecieron ya en el siglo XVI en las ciudades de la periferia peninsular más integradas con las economías exteriores ${ }^{69}$. Por lo tanto, el asentamiento de una comunidad en una ciudad portuaria es algo relacionado directamente con la cuestión y también la realidad del crecimiento económico de estos enclaves urbanos, que eran al mismo tiempo una ciudad marítima importante en la economía internacional, especialmente la atlántica.

De entre los diversos factores que condicionaron la aparición de los consulados algunos estaban muy relacionados con el mantenimiento de la integridad de los negocios de los extranjeros. Las actividades económicas estaban organizadas en torno a compañías de comercio internacional y redes familiares que extrapolaron los intereses de la comunidad local al plano internacional. La práctica del comercio necesitaba una seguridad económica, jurídica y social que exigía una reglamentación que asumiese lo distintivo de cada grupo y protegiera los intereses, aún más si en el seno de estas comunidades se estaba formando una élite diferencial del todo de la denominada «nación» mercantil que acogía, eso sí, a emigrantes de diferente condición social y económica. En muchos casos, como sucedía en las ciudades de Levante español, como Valencia, Cartagena o Alicante, la formación de compañías de comercio extranjeras en las ciudades españolas más desarrolladas económicamente exigía una formalización en libros o documentos acreditativos, con objeto de que hubiese un control jurídico de las compañías de comercio organizadas, que fue utilizado a veces por las autoridades locales para proceder a su control ${ }^{70}$. Esto no ocurría siempre así. Hay que afirmar en honor a la verdad, que la mayor parte de las comunidades se salvaban, por así decirlo, de este control y todas las cuestiones referentes a los problemas de las firmas y las compañías se resolvían en privado, en juntas organizadas por parte de los hombres de negocios más pudientes, pero éste fue también uno de los puntos de conflicto con las autoridades y la junta.

${ }^{69}$ Montojo Montojo, Vicente, «Crecimiento mercantil...», pág. 49.

${ }^{70}$ Ocurría en algunos casos, como los descritos para Alicante y Cartagena, por MONTOJO MonTOJO, Vicente, «Crecimiento mercantil...», pág. 51. 
En muchas ocasiones los cónsules se tenían que implicar en problemas de rivalidad política que a veces eran nocivos para las colonias a las que supuestamente representaban. Ocurrió en el caso inglés en 1714 cuando la Corona inglesa pretendía hacer fortificaciones en Gibraltar en contra de los deseos de la Corona española, que aprovechó para desestimar las reclamaciones sobre los perjuicios hechos a mercaderes ingleses, residentes en España, durante la Guerra de Sucesión. La protesta española es obvia ya que era algo contrario a lo acordado en Utrecht. Fue a partir de 1714, con la negativa de entregar Menorca a España, cuando empezó a haber desavenencias entre las dos cortes, por lo que España decidió arreglar la paz con Holanda ${ }^{71}$.

Tanto los comerciantes ingleses (desde el tratado de 1667, en el que España ante la amenaza de guerra con Francia hubo de ceder y reconocerles amplios derechos), como los franceses (desde 1659, por la Paz de los Pirineos, y sobre todo desde 1700) y sus respectivas comunidades recibieron unos privilegios desconocidos en la época anterior (en tiempos del conde duque de Olivares eran nombrados españoles como cónsules de estas naciones), por lo que en 1714 se procedió desde la Junta a revisar desde una posición de fuerza no sólo las renovaciones de los cónsules (se dispuso, por ejemplo, no aceptarlos procedentes de estados que no los tuvieran en el reinado anterior) sino también sus competencias en la medida que pudieran chocar con las de las autoridades españolas. La recuperación borbónica de Cartagena y Alicante, por ejemplo, dio lugar a una actuación más dura en el control del tráfico mercantil en sus puertos, asumida por oficiales militares, provocando un serio rechazo entre los comerciantes y cónsules $^{72}$. Pero además los excesos de los cónsules en el ejercicio de sus cargos eran frecuentes. El papel del cónsul, sin embargo, podía ser eficaz en tiempos de conflicto bélico. Las redes entre mercaderes-cónsules y estadistas funcionaban normalmente en relación a la eficacia de la información, que se canalizaba a través de estas redes. En 1754 el cónsul británico en Cádiz informó al duque de Newcastle sobre la presencia de soldados franceses en la Bahía ${ }^{73}$.

Otros casos descritos en los informes de la Junta de Dependencias de Extranjeros hacían relación a algunas prácticas realizadas por los cónsules, muchas de ellas ilícitas. El 15 de febrero de 1754 Pedro Álvarez, juez visitador, envió un escrito al marqués de la Ensenada sobre algunas de estas prácticas como la realizada por el cónsul holandés de Canarias, Arnaldo Vastinfort, que sobornaba a los escribanos nombrados en Cádiz para el despacho de navíos desde Cana-

${ }_{71}$ AGS. Secretaría de Estado, leg. 6826.

72 AHNM Estado, leg. 463, sn, 31-X-1707. El obispo Belluga informó a Grimaldo de los abusos de Patricio Miset, castellano de Cartagena, en la práctica del puerto, obligando a los barcos a cargar y descargar con barcas del puerto y no propias. Poco después Miset fue destinado a Alicante, con un cargo parecido.

73 British Library (en adelante BL) Additional Manuscrits (en adelante: Add. Mss.) 3268632992: Correspondencia oficial de Sir Henry Thomas Pelm, duque de Newcastle; y 32849: Notificación de cónsul inglés al Duque de New Castle, 1754. 
rias a América. Dijo el Juez visitador, que «unos las venden por dinero y los que así no lo hacen como lo practica el cónsul de Holanda era para tener en el navío quien llevase y cuidase de sus intereses» ${ }^{74}$. Era muy común cambiar el nombre de los buques y con toda la mercancía introducirlos en las flotas y galeones que se pertrechaban en Cádiz. La escasez de barcos en España hacía de este recurso como una tabla de salvamento también para los mercaderes españoles ${ }^{75}$.

En la década de 1730 se revisaron las leyes para los nombramientos de cónsules de las naciones extranjeras y de los jueces conservadores, aprobándose los nombramientos del juez conservador de la nación holandesa de Sevilla, Sanlúcar y Ayamonte, a favor de Pedro Masior y Monteverde, siendo Germán Neúyen, cónsul holandés en Sevilla ${ }^{76}$. También se nombró cónsul de Holanda en La Coruña en la persona de Adrián Berkenhourt ${ }^{77}$. A veces, algunos comerciantes de las ciudades ejercían ilegalmente el empleo de cónsul, algo que era bastante habitual, como sucedió con Antonio Bartolón en Almería (1724). En este caso, la Junta de Dependencias pudo imponerle una multa ${ }^{78}$. Problemas semejantes parecían afectar a los nombramientos de cónsules de Venecia en Alicante (Juan Bautista Fabiani), o de Génova en Barcelona (Pedro María Merizano) y Mallorca. Pero se trasluce que algunas colonias eran objeto de mayor o menor xenofobia en determinadas ciudades ${ }^{79}$. En el caso de Malta, por ejemplo, los embajadores pedían que los cónsules de dicha isla se encontrasen en las mismas condiciones que los de otras potencias y así se aprobó un consulado de Malta en Denia en 1724 (Bernardo Polart) ${ }^{80}$.

Otra de las competencias de la Junta de Dependencias se reflejó en una preocupación por hacer recuentos regulares de todos los ciudadanos extranjeros residentes en su territorio. Esta normativa se puso en marcha de forma más o menos eficaz a partir de 1714 , pero fue en la segunda mitad del siglo XVIII cuando se tomaron más en consideración, tras la intervención de España en la Guerra de los Siete Años y su fracaso ante Inglaterra. En 1764 una real cédula de Carlos III dispuso que con carácter anual «se forme en todos los Puertos y Lugares de Comercio una lista de los comerciantes y demás personas extranjeras que haya en ellas» ${ }^{81}$. Más adelante se promulgó una real cédula firmada el

${ }_{74}$ Citado en Ramos, Luis J., «Navíos extranjeros habilitados como nacionales para efectuar el comercio con América a mediados del siglo XVIII», en: II Coloquio de Historia Canario-Americana (1977), Las Palmas de Gran Canaria, 1979, págs. 21-32.

75 Crespo SolanA, Ana, El comercio maritimo entre Ámsterdam y Cádiz (1713-1778), Madrid, 2000, págs. 79-89.

76 AHNM Estado, leg. 606, Caja 1. Consulta original resuelta por S.M. 26/8/1737.

77 AHNM Estado, leg. 606, Caja 1. Consulta de 28 de febrero de 1737

78 AHNM Estado, leg. 605, exp.12 y 13. 4-5-1724. Memorial de Antonio Bartholón, de Almería.

79 AHNM Estado leg. 606/ 872, 1738-1739.

80 AHNM Estado leg. 605/ 611. Carta del Embajador de Malta en España Dávila y Guzmán, 1724.

81 AHNM Estado, leg. 629. S.f., cit. JARQUE MARTíneZ, Encarnación y SALAS AuSENS, José Antonio, «Extranjeros...», págs. 985 y ss. 
20 de julio de 1791, por la que debía constar el nombre, la procedencia, el estado civil, el nombre de la esposa si se trataban de casados, el número de hijos, la profesión, el credo, la localidad de asentamiento, los años de residencia y la condición de avecindados y transeúntes. El grado de cumplimiento de todas fue algo muy relativo, a lo que se une la escasa credibilidad de estas listas oficiales. Hoy día queda fuera de toda duda que las colonias de extranjeros residentes o transeúntes en España eran más numerosas de lo que nunca pudo comprobarse en su época e incluso en la reciente historiografía sobre el tema. La dificultad de poder recabar información real en las capitanías generales y en las intendencias provinciales fue recogida en los trabajos realizados por José Antonio Salas Ausens ${ }^{82}$. En estas disposiciones se daba importancia a una serie de cuestiones, como el ser avecindado o transeúnte, o el credo religioso del individuo. No hay más que leer el contenido de todas las medidas administrativas para notar que la Corona era consciente de cuál era el oficio que principalmente venían a desempeñar y qué tipo de ciudades aquellas preferidas de asentamiento: comerciantes en ciudades portuarias de la Monarquía. De hecho, para algunos comerciantes extranjeros el consulado era una aspiración atractiva, puesto que el cargo ostentaba inmunidad y otros privilegios. De aquí, por ejemplo, la tendencia de genoveses e irlandeses a pedir el nombramiento de cónsules ${ }^{83}$.

\section{La Junta de Dependencias de Extranjeros y SuS Problemas en el LEVANTE}

La Junta de Dependencias y Negocios de Extranjeros surgió en un contexto en el que, tras la Guerra de Sucesión que había afectado fuertemente al tráfico mercantil, se estaba empezando a producir una recuperación económica notable, más acusado en las ciudades portuarias de la Monarquía muy conectadas con el exterior $^{84}$. Uno de los negocios que empezaron a ser de nuevo boyantes fue el de la tradicional exportación de lanas y otras materias primas o el tráfico con América. En consecuencia la paz de Utrecht permitió de nuevo la generalización del tráfico (pronto interrumpido por nuevos conflictos), pero en lo que se refiere al Levante español, sede de importantes comunidades extranjeras, también la renovación de sus representantes consulares, con consecuencias que se habían adelan-

82 Jarque MartíneZ, Encarnación y SALAs AuSEnS, José Antonio, «Extranjeros...», pág. 990; SAlas Ausens, José Antonio, «Leyes de inmigración y flujos migratorios en la España moderna», en: Villar García, María Begoña y Pezzi Cristobal, Pilar (eds.), I Coloquio Internacional «Los Extranjeros en la España Moderna», Málaga, 2003, 2 tomos, vol. II, págs. 681-697.

${ }_{83}$ El consulado de Roma en Alicante fue pedido por Juan Bautista Escot, francés, Juan Domingo Grasi, genovés, y Cristóbal Hall, irlandés, a quienes fue denegado por no ser romanos: AHNM Estado, 627, expt. 27; 607, 1 expt. 2 y 641, expt. 11 (1715 y 1727).

84 SALVADOR ESTEBAN, Emilia, «La frontera intrarregnícola valenciana y su impacto en las instituciones reales. El ejemplo de las dos bailías generales», Pedralbes, 13 (1993), págs. 11-23, cfr. 19. 
tado, como la resistencia de los comerciantes a través de diputados a la continuidad de ciertas exacciones fiscales características de tiempos de guerra.

La actuación de los negociantes extranjeros asentados en el área levantina española fue objeto de estudio por parte de las autoridades ${ }^{85}$, que, en semejantes circunstancias, se revistieron de múltiples formas de resistencia, desde el recurso a la intermediación de los embajadores y la natural protección de los cónsules (en ello se manifiesta el colectivo foráneo como un grupo de presión) hasta el ejercicio del contrabando, el cual se había sostenido durante la guerra como se hacía antes.

Es comprensible que la Junta de Dependencias de Extranjeros hubiera de reunir los antecedentes de sus actuaciones, como algunos títulos de nombramientos de cónsules extranjeros del último cuarto del siglo XVII, lo cual se puede entender más fácilmente teniendo en cuenta que se adoptó el criterio de no admitir cónsules de estados que no los hubieran tenido durante el reinado de Carlos II. Precisamente en Alicante se operó un aumento de los cónsules extranjeros, a diferencia de en Cartagena, ciudad portuaria próxima en la que no todos estos estados mantuvieron representación. El establecimiento de cónsules por Holanda, Francia e Inglaterra en determinados puertos españoles ha sido considerado tradicionalmente como una manifestación del poder económico de estos estados a mediados del siglo XVII ${ }^{86}$. Al mismo tiempo, desde una perspectiva referente al Levante español, la inclusión de Alicante entre el grupo de puertos en que fueron puestos cónsules holandeses, con preferencia sobre Valencia y Cartagena, ha sido también considerada como un ejemplo de la importancia de Alicante en el contexto del tráfico mercantil del Mediterráneo español ${ }^{87}$.

El carácter plurinacional de sus comunidades chocaba con la tendencia uniformadora de los grandes estados como España, pero simultáneamente la beligerancia con Inglaterra y Austria por la recuperación de territorios en Italia obligaba a la dependencia de Francia. Por otra parte, en la composición de estas comunidades había además otros elementos a tener en cuenta, como la presencia de exiliados (ingleses e irlandeses católicos, armenios cristianos) y de artistas, todos ellos con privilegios o trato de favor, o de índole estratégica en el caso de los comerciantes que auxiliaban a los proveedores del ejército. Al mismo tiempo, la perduración de estas comunidades se facilitaba mediante condiciones concretas de cooperación o ayuda. Podían darse al mismo tiempo en

${ }^{85}$ El agente fiscal del Consejo de Guerra Francisco de Oya Ozores redactó un Prontuario del comercio de extranjeros, que por medio de la Junta fue dado a conocer al rey (AHNM Estado, legajo 620/1, n. 17, 1728).

86 KAMEN, Henry, La España de Carlos II, Barcelona, 1981, pág. 181; SÁNCHEZ BelÉN, Juan Antonio, «El comercio de exportación holandés en el Mediterráneo español durante la regencia de doña Mariana de Austria», Espacio, Tiempo y Forma, serie IV, Historia Moderna, 9 (1996), págs. 267-321.

87 GimÉnez LóPEZ, Enrique, «El puerto en la Edad Moderna», en: Moreno SÁEZ, Fernando, Historia de Alicante, Alacant, 1989, I, págs. 306-310; BIBILONI AMENGUAL, Antonio, El comerç exterior de Mallorca. Homes, mercats i productes d'intercanvi (1650-1720), Mallorca, 1995, págs. 212-224. 
estas comunidades diferencias significativas que conviene tener en cuenta. Entre los ingleses de Alicante, por ejemplo, destacaba la presencia de algunos católicos, que no se daba en Cartagena, de tal forma que aquellos consiguieron superar los periodos de guerra, mientras que en Cartagena no sucedió lo mismo. Al acabar la Guerra de Sucesión, a la par que se produjo la recuperación de la exportación de sal y otros productos levantinos (1709-1713) $)^{88}$, la instauración de la Junta de Dependencias de Extranjeros, primero en 1714-1718 y después en 1721-1748, fue paralela al surgimiento de continuos problemas con los nuevos cónsules extranjeros ${ }^{89}$. Éstos representaban a las comunidades extranjeras, de composición sobre todo mercantil, que proporcionaron importantes ingresos dinerarios al rey y a las autoridades regnícolas y locales, además de artículos de lujo para la nobleza de la corte madrileña y de alimentos básicos para el abasto de las poblaciones, por lo que constituían un colectivo fundamental en las relaciones políticas y sociales, dado el ascendiente de los embajadores en la corte, en especial el francés. Pero habían adquirido también ciertos derechos (representación consular, juez conservador) y privilegios (costumbres propias de albaceazgo, inventario y partición de bienes), a los que los tratados comerciales y de paz daban fuerza y con los que estaban apegados. De aquí que una vez que la guerra hubo terminado y no se justificó ya la fuerte presión fiscal, se produjo un fuerte enfrentamiento entre las autoridades alicantinas y algunos cónsules extranjeros, como en especial el francés Juan Bigodet ${ }^{90}$ y el inglés Nicolás Herne ${ }^{91}$ en Alicante.

Si en el reinado anterior, el de Carlos II, Alicante se había destacado por su concentración de cónsules extranjeros, como los de Génova (Pablo Félix de Cosme desde 167592), Venecia (lo tenía desde 158593), Holanda (desde 1649),

\footnotetext{
${ }^{88}$ Montojo Montojo, Vicente, «Los comerciantes de Alicante y Cartagena en la Guerra de Sucesión», Estudis. Revista de Historia Moderna, 34 (2008), págs. 219-239.

89 En 1709 se reinstauró a Juan Bta. Corsiniani como cónsul de Florencia (AHNM Estado, legajo 611, n. 62), que lo era desde 1680 (AHNM Estado, legajo 641/2, n. 43), y en 1710 a Gaspar Bustanzo como cónsul de Génova (AHNM Consejos, legajo 641, n. 9, 20-2-1727). Corsiniani fue además administrador de la aduana de Alicante (AHNM Consejos, leg 619/2, n. 34, 5-7-1714) y regidor del Ayuntamiento borbónico.

${ }^{90}$ AHNM Estado leg. 609/1, n. 13, 12-3-1715 (denegación) y n. 39, 3-12-1714; 627, n. 8, 9-8-1715 (no prórroga) y n. 14, 24-8-1715 (intentó introducirse en la jurisdicción real en cuanto a un pleito con genoveses); 617/1, n. 18, 8-2-1716; 618/1, n. 5, 23-2-1717 (denegación derechos consulares). Continuó con su hijo y sucesor, Pedro Bigodet de Varennes: Estado 623/1, n. 8, 1722; 623/2, n. 43, 13-11-1722; 2893, n. 10, 1722 y 612, n. 32, 26-9-1723 (se denegó que nombrase un vicecónsul en Valencia).

91 AGS Secretaría de Estado, leg. 6837.

92 AHNM Consejos, leg. 609/2, n. 43.

93 Tras Pedro Cresafida (1722) lo solicitó Juan Bta. Fabián, a quien se le denegó por ser genovés en 1728, especificándose claramente que Alicante había mantenido un cónsul veneciano en el reinado de Carlos II, mientras que Cartagena no lo mantuvo (AHNM Consejos, leg. 620/1, n. 7 y leg. 605/1, n. 15, 4-5-1724).
} 
Francia (1659), Inglaterra (1660), o Dinamarca, Suecia y Ciudades Hanseáticas (Hamburgo), por contraste con la época de Felipe IV en que se impuso el nombramiento de nacionales como cónsules extranjeros ${ }^{94}$ e incluso a un cónsul de las naciones extranjeras, Carlos II hubo de admitir que fueran extranjeros y, por lo tanto, más difíciles de controlar.

El reconocimiento de cónsules extranjeros fue ya de por sí problemático con Felipe V, siendo controlado primero por el Consejo de Estado (hasta 1714), después por la Junta de Dependencias y Negocios de la Nación Francesa, llamada luego Junta de Dependencias y Negocios de Extranjeros, para pasar finalmente a la Junta de Comercio, Moneda y Minas95. Se exigían ciertas condiciones para aceptar cónsules, como la ya mencionado de que los hubiera en el reinado anterior, que no tuvieran cargos públicos nacionales, que se prefiriera al nacional sobre el extranjero y su oficio sin jurisdicción. El gobernador militar debía informar al Consejo, o luego a la Junta, sobre la idoneidad del aspirante, cuyo oficio debió tener atractivo por sus prerrogativas. La relación del gobierno con los cónsules extranjeros era en gran parte una prueba de la capacidad de sujetar unas comunidades foráneas que eran importantes, pues su fuerza estaba además en la necesidad del apoyo de las monarquías europeas, en un escenario diplomático en el que España había quedado relegada tras las guerras con Francia y sus aliados. En el caso de Alicante, la resistencia de los cónsules francés e inglés se dirigió sobre todo contra la implantación primero de la fiscalidad castellana y después del equivalente valenciano, con las medidas que acompañaron de mayor presión fiscal, en especial sobre el comercio, y con algunas otras añadidas, como la supervisión de los libros de los comerciantes. Estos adujeron distintas excusas para no hacerlo, como el hecho de haberlos enviado a Inglaterra en el caso de los británicos, cuando la guerra les impidió permanecer en Alicante ${ }^{96}$. El cónsul francés, por su parte, llegó a oponer una tenaz resistencia a que se hiciera pagar a los franceses el cuartel de invierno, llegando a rechazar a los soldados por la fuerza, con gran repulsa de las autoridades ${ }^{97}$.

La confrontación entre la Junta de Dependencias y Negocios de Extranjeros y los ingleses no se limitó a Alicante, pues se extendió también a Peñíscola (Valencia), desde donde se quejaron de la introducción de un nuevo impuesto sobre la exportación de vino que ellos realizaban, como parte del cambio fis$\mathrm{cal}^{98}$, o a Málaga, por razón del inventario de bienes de uno de ellos ${ }^{99}$. En líneas generales, predominó el problema fiscal en estas conflictivas relaciones, pero

${ }^{4}$ Pradells Nadal, Jesús, Diplomacia y comercio: La expansión consular española en el siglo XVIII, Alicante, 1992, págs. 37-38.

${ }^{95}$ Castro Martos, M. ${ }^{\text {a }} \mathrm{Paz}$, «El Archivo del Consejo de Estado», Boletín de la Asociación Española de Archiveros, Bibliotecarios, Museólogos y Documentalistas, 1 (1996), págs. 119-138, cfr. 134-136.

${ }_{96}$ AHNM Estado, leg. 620/1, n. 5, 20-2-1728.

97 AHNM Estado, leg. 619/2, n. 34, 1714.

98 AHNM Estado, leg. 617/1, n. 31, 6-3-1716.

99 AHNM Estado, leg. 617/1, n. 26, 21-2-1716. 
también la colaboración de los cónsules extranjeros con el contrabando, todo lo cual era signo de la dependencia económica de España con respecto a las manufacturas de algunos estados de Europa Occidental y de la ausencia de una industria fabril española, por lo que los comerciantes extranjeros eran imprescindibles en el tráfico de Levante.

Esta situación se dio asimismo con una cierta dispersión geográfica de las comunidades. Así, la ciudad de Murcia, concentró también comunidades extranjeras de genoveses y franceses, pero a diferencia de Alicante y Cartagena, donde abundaban los comerciantes mayoristas, en ella predominaban los minoristas o de puerta abierta ${ }^{100}$. Cuando en 1741 estos comerciantes pidieron alguna exención de contribuciones la Junta contestó que sólo a los mayoristas de los puertos marítimos se les podía conceder ${ }^{101}$.

\section{LOS PROBLEMAS DEL COMERCIO CON AMÉRICA SEGÚN LOS ASUNTOS TRA- TADOS EN LA JUNTA}

El comercio americano era uno de los temas más recurrentes en los memoriales de extranjeros y ponía en evidencia la existencia de una red de intereses que a veces sobrepasaba las fronteras nacionales, aunque también reflejaba grandes rivalidades. Esto último a veces no era contradictorio con la transnacionalidad de los intereses mercantiles. A partir de 1714, su desarrollo está muy relacionado con los diversos intentos de formar una junta en la corte compuesta por diputados elegidos por provincias entre las personas más experimentadas en cuestiones de comercio. Por ejemplo, se envió a la Corte una

${ }_{100}$ Murcia, situada a $80 \mathrm{~km}$ de Alicante y a 45 de Cartagena, era una etapa importante en las rutas de los reinos de Granada y Toledo. En 1730 llegó a la Junta una queja del embajador de Francia por haberse inmiscuido el alcalde mayor de Murcia en hacer el inventario de bienes de Juan Danthoine Rolan, francés casado con francesa que llevaba 30 años en Murcia. El embajador alegó que según una ley francesa el rey había de heredar a los peregrinos intestados. Su hijo Benito Danthoine Bafier vivía en Puerto de Santa María y su hija Margarita Danthoine Bafier en Marsella, casada con Juan Francisco Savi. Resultó que Juan Danthoine sí había hecho testamento y en Murcia no había cónsul ni juez conservador por lo que siempre intervenía el alcalde mayor (AHNM Estado, legajo 608/1, n. 15).

${ }^{101}$ En 1711-1749 hubo 10-20 mercaderes franceses en Murcia, la mitad del total, y sólo unos pocos genoveses como Jerónimo Mucio y Marcelo Merano (Archivo Municipal de Murcia, legajo 2792, n. 1, 1711-1713 y Archivo Histórico Provincial de Murcia, Prot. 3300, fs. 73-82, 17-3-1727 y 3324, fs. 87-89, 7-4-1749). La petición de exención la hicieron Antonio Platel y Pedro Estachaile. El fiscal argumentó que los privilegios eran para los comerciantes mayoristas de los puertos marítimos y para los transeúntes en el interior, «pero no por lo tocante a los que se establecen en las ciudades interiores, tienen sus casas pobladas de muchos años, con tienda abierta, vendiendo por mayor y menor, gozando de todos los emolumentos y aprovechamientos que pertenecen a los vecinos naturales de estos reinos, pues éstos deben estar sujetos a la satisfacción de las reales contribuciones, de sus pleitos y causas de las justicias de los pueblos en que residieren» (A.H.N.M, Estado, legajo 607/1, n. 12, 11-2-1741). 
Memoria con los «medios para conseguir el desarrollo mercantil de España» que proponía una junta que gobernaría con patente real, resolvería todas las causas de primera instancia o que se le presentaran en apelación de sentencias dadas por los consulados o jueces de alzadas, simplificando de esta manera los litigios. Exponía, entre otras cosas, una serie de medidas para evitar el comercio ilícito de los extranjeros en América de las mercancías intercambiables entre España e Inglaterra ${ }^{102}$. Proponía algunas ideas, quizá no muy prácticas, pues creía que una forma para evitar el contrabando en América era aumentar el sueldo de los gobernadores y oficiales y armar navíos de guerra, veleros y fragatas que estuvieran siempre en las costas de Veracruz y Callao ${ }^{103}$.

Desde la segunda mitad del siglo XVII, se pretendía vigilar la actividad comercial de los mercaderes extranjeros asentados en suelo español con la América española. Es por ello, y aunque no fue la razón principal de las reformas, que en las tres primeras décadas del siglo XVIII, afectaron a los tribunales del monopolio americano, por lo que el comercio colonial que ejercían los extranjeros en algunas ciudades sí desempeñaba un argumento de peso para que la Corona española reforzara las medidas de control sobre estas actividades. Las colonias de mercaderes y muchas firmas de comercio particular elevaron memoriales y anteproyectos de posibles negocios. Los memoriales eran también un mecanismo de autorrepresentación de la identidad y una forma de defensa de los intereses mercantiles.

Varios eran los temas más considerados en estos memoriales, vistos de un modo general. Un problema que preocupó a la Junta fue el comercio de la Compañía del Asiento de negros, pues el propio ministro José Patiño solía afirmar que el comercio español no podría ser reformado hasta que no terminase dicho asiento. Según Malachy Postlethwayt, en su Universal Dictionary of Trade and Commerce, el Asiento se hizo para que las compañías inglesas surtieran a las Indias occidentales españolas de esclavos negros por término de 30 años, comenzando el 1 de mayo de 1713 y terminando ese día de 1743. Uno de los artículos del Asiento decía que durante el tiempo del contrato los ingleses debían ser tratados en los puertos españoles de América como si fueran súbditos de la Corona británica pero con la restricción de que en los dichos puertos no debían residir más de 4 o 6 ingleses. En todos estos puertos debía haber un Juez conservador del Asiento, cuestión que fue tratada por Thomas Powles, residente en Madrid, encargado de los negocios de la Compañía del Asiento de Negros ${ }^{104}$. Con todo, los asuntos ingleses parecen estar llenos de contradicciones, ya que a pesar del recelo que la Corona española tenía de su presencia en la América hispana por el alto contrabando que realizaban aprovechando los buques del Asiento, se continuó otorgando recomendaciones y

\footnotetext{
${ }_{102}$ AHNM Estado, leg. 3188, n. 414.

103 AHNM Estado, leg. 3188, n. 414.

${ }_{104}$ POSTLETHWAYT, Malachy, Universal Dictionary of Trade and Commerce: with a large additions and improvement, London, $1774,4^{\circ}$ ed., vol. 1. Voz Asiento.
} 
permisos a algunos negociantes irlandeses para negocios con América. Fue el caso de Roberto Shee, caballero católico irlandés, que recibió un permiso para fletar dos buques mercantes ingleses a las Indias españolas ${ }^{105}$. Los permisos a negociantes irlandeses fueron numerosos en la década de 1720 y podría haberse dado el caso de que en la Junta se hubiese pensado apoyar a los irlandeses con objeto de tenerlos como aliados contra los ingleses. Luke Schaub, secretario de Stanhope hacia 1720, recibió un pasaporte especial de la mano del ministro José Patiño para salir de viaje a Viena con objeto de negociar algunos de los artículos del acuerdo de la Cuádruple Alianza entre España e Inglaterra. Schaub afirmaba que una de las posibles razones en contra de solucionar los problemas con el Imperio era que el rey de España aún consideraba al emperador como un rival y no deseaba prescindir de sus planes italianos. Como contrapartida, el gobierno inglés estaba reacio a apoyar a España en esta política y una de las razones era, según apuntaba el entonces embajador inglés en La Haya, Horacio Walpole, la idea de la conspiración jacobita en la que supuestamente estaban involucrados algunos miembros del gobierno español, Campillo y Alberoni al parecer, que estaban a favor de colaborar con los banqueros irlandeses en el exilio en sus planes de reconquista de la corona inglesa para el pretendiente Estuardo. Es muy probable que esto incidiera no sólo en la falta de apoyo inglés a España en la década de 1720 sino en la propia caída del ministro italiano, Alberoni, después de la campaña de Italia ${ }^{106}$. Schaub recibió posteriormente una misión relacionada con los asuntos de Nueva España y los intereses de la Compañía del Asiento de negros. No está claro si Patiño le encargó que fuese a México a servirle de espía sobre las actividades de la Compañía inglesa tal como una carta fechada el 9 de julio de 1720 parece confirmar ${ }^{107}$.

El problema de Francia parecía también terminarse con la guerra de Sucesión española ya que con la venida del nuevo Anjou español se logró dar carta blanca a la expansión francesa en América, algo que los propios ingleses temían. Por ejemplo, en un memorial redactado por Lucas Schaub describía los intentos de Francia de ocupar algunos puertos mexicanos, provocando una ofensiva de la armada española en 1686. Tras el cambio de dinastía, en 1713 se suspendieron los intentos de expulsar a los franceses e incluso el propio virrey de Nueva España los socorrió cuando estos estaban faltos de víveres. Después de la Paz de Utrecht se firmó en París la Compañía del Misissipí y Francia ocupó Panzacola en 1719, cuando estaba en guerra con España aunque no se expulsó a los franceses de ésta. Los representantes ingleses defendieron la falta de derecho de Francia a ocupar ese territorio ya que pertenecía al rey de España, salvo los territorios bajo la órbita británica de Virginia (lindante con la Florida española), la Carolina, Nueva Inglaterra, que, según el memorialista Schaub

\footnotetext{
105 AGS Secretaría de Estado, leg. 6827.

106 BL Add. Mss. 4204, Letter of Sir Lucas Schaub, Madrid, 3 de junio de 1720.

107 BL Add. Mss. 4204, Letter of Sir Lucas Schaub, 9 de julio de 1720, fol. 95.
} 
«hace mucho la poseyeron la corona de la Gran Bretaña, cuyos dominios experimentaron con el tiempo (si los franceses subsisten en la Ribera del Misissipi) considerables perjuicios como la España en el reino de México y bien sabe el Almirantazgo de la Gran Bretaña que si franceses tiene puerto en el seno mexicano en tiempo de guerra no pueden sus flotas de Jamaica pasar a desembocar la canal de Bahama, sin el evidente peligro de ser atacadas de las escuadras de Francia, por cuyos motivos deben la España y la Gran Bretaña hacer que cada uno se contenga en sus derechos»108.

Una correspondencia entre Roberto Shee y Antonio de la Rosa, sobre la situación económica de la Compañía del Mar del Sur entre 1714 y 1731, evidencia que el comercio inglés en América era algo preocupante para la Corona española, pero también era una cuestión diplomática que implicaba, hasta cierto punto, la necesidad de una cooperación hispano-británica que pronto se vería entorpecida por la guerra en el Caribe (denominada Guerra de la Oreja de Jenkins o del Asiento) y que eliminó cualquier posibilidad de entendimiento entre las dos coronas. Roberto Shee se quejaba al estadista español de la ruina de numerosas familias inglesas por la baja de las acciones de la Compañía del Mar del Sur ${ }^{109}$. Así se puede entender el recurso de España a la colaboración de los mercaderes irlandeses. De hecho, el Parlamento británico acusó al ministerio español (especialmente al liderado por José del Campillo) de prestar asistencia al pretendiente jacobita al trono inglés, algo que temían los británicos debido a la posibilidad de una alianza franco-española para invadir Inglaterra y volver a instaurar la rama católica en el trono de Inglaterra ${ }^{110}$. El Tratado de Madrid, firmado el 14 de diciembre de 1725 , y en el que participó el embajador y ministro inglés Paul Methuen, pudo aclarar algunas cuestiones relacionadas con estos problemas comerciales bilaterales pero las quejas de los mercaderes ingleses ante los decomisos de mercancías y detención de navíos mercantes que llegaban a puertos hispanos deterioró la posibilidad de mejores entendimientos.

En este contexto, el proyecto del mercader Guillermo Eón, "para impedir el comercio ilícito en las Indias españolas» (1726), hasta cierto punto refleja también el interés de los mercaderes ingleses en España por mantenerse al margen de los problemas diplomáticos entre España e Inglaterra ${ }^{111}$. Guillermo Eón fue secretario de la Compañía del Asiento de Negros y transmite algunas noticias escritas por los factores de la Compañía del Mar del Sur en América, informando de los daños que hacían a la compañía los piratas. Proponía una forma de hacer el pago de los negros transportados a América desde Guinea ${ }^{112}$. Los mercaderes extranjeros también presentaban memoriales a la Junta de De-

\footnotetext{
108 BL Add. Mss. 4204, Memorial de Sir Lucas Schaub, fol. 381-383.

109 AGS Secretaría de Estado, leg. 6828.

110 AGS Secretaría de Estado, leg. 6830.

111 AGS Secretaría de Estado, leg. 6832.

112 AGS Secretaría de Estado, 6840.
} 
pendencias de Extranjeros con objeto de plantear posibles proyectos comerciales con el visto bueno de la Corona, como el memorial de la Compañía de Bernardo Van Dahrl y consortes (1764-1765), procedente de Cádiz ${ }^{113}$.

\section{CONCLUSIÓN}

Una historia general de la Junta de Dependencias de Extranjeros es un reto importante para comprehender la larga evolución de las actividades y la propia condición de los extranjeros en España, en los siglos de la Edad Moderna. Nuestra intención es profundizar en esta evolución a la par que averiguar la compleja dialéctica existente entre las leyes contra los extranjeros y los sucesivos esfuerzos de las autoridades españolas, en todos los frentes, por escuchar, atender y colaborar con ellos. Las irregularidades y conveniencias de la relación entre la administración y los extranjeros estuvieron tan llenas de avatares como la propia trayectoria de la Junta de Dependencias. Suprimida en 1717 debido a razones bélicas, se volvió a establecer por decreto del 3 de noviembre de 1721 y perduró hasta otro decreto del 21 de diciembre de 1748 , fecha en la que se extinguió pasando sus asuntos a la Suprema Junta General de Comercio y Moneda. En su esencia, los asuntos que trató tuvieron alcance internacional y fue de gran importancia para las proyecciones de España en Europa. En cierto sentido se puede decir que la Junta de Dependencias de Extranjeros mostró un modo de relación distinto del gobierno con las comunidades mencionadas, en contraste con la actuación de las juntas del contrabando anteriores y la Junta de Comercio, Moneda y Minas posterior. En su esencia, tras la instauración de la dinastía Borbónica en España, la Junta de Dependencias de Extranjeros rompió la dinámica de juntas anteriores como la de Comercio de 1679 o las juntas de comercio y contrabando puesto que estas se dirigían ya a fomentar el comercio nacional español o a perseguir el fraude fiscal. Por contraste la de Dependencias fue una junta muy conciliadora con las comunidades extranjeras restableciendo viejos privilegios y prerrogativas que los propios representantes de las comunidades defendieron ante la administración española. La nueva política pareció afectar más a las comunidades asentadas en ciudades portuarias del Levante y Andalucía donde eran más numerosas.

Recibido: 15-10-2008

Aceptado: 24-03-2009

113 AHNM Estado, leg. 3208, n. 347. 